\title{
How do Employers Respond to an Aging Workforce? Evidence from Surveys
}

\section{Among Employers, 2009-2017}

\author{
Jaap Oude Mulders, Kène Henkens and Hendrik P. van Dalen
}

Jaap Oude Mulders, Netherlands Interdisciplinary Demographic Institute, The Hague, The Netherlands, oudemulders@ nidi.nl [Corresponding author]

Kène Henkens, Netherlands Interdisciplinary Demographic Institute, University Medical Center Groningen and University of Amsterdam

Hendrik P. van Dalen, Netherlands Interdisciplinary Demographic Institute and Tilburg University

This study has appeared as a chapter in an edited volume:

Oude Mulders, J., Henkens, K., \& Van Dalen, H.P. (2018). How do employers respond to an aging workforce? Evidence from surveys among employers, 2009-2017. In S.J. Czaja, J. Sharit, \& J.B. James (Eds.), Current and Emerging Trends in Aging and Work (pp. 291-296). Springer. https://doi.org/10.1007/978-3-030-24135-3_14

\begin{abstract}
Employers are central actors in shaping employment opportunities for older workers and facilitating longer working lives. In this chapter, we study the ways in which employers have adapted their attitudes and organizational policies and practices to deal with an aging workforce. We do so by comparing data from two large surveys on the topic of workforce aging among employers in the Netherlands, held in 2009 and 2017. The Netherlands forms an interesting case study as it is in the midst of transitioning from a society with high rates of early retirement to one with comparatively high employment participation rates of older workers and an increasing statutory retirement age. The results show that employers have strong concerns regarding the costs of employing an aging workforce and about potential negative effects of aging on organizational productivity. At the same time, however, employers have become much more active in offering human resource practices aimed at accommodating and training older workers, and employers are overall more supportive of work at higher ages. Overall, we identify a growing sense of urgency among employers to invest in longer working lives and ensure the long-term work ability of older workers. However, there remains a strong desire for policy changes that offer a lower statutory retirement age for workers in physically demanding jobs or a more attainable form of part-time retirement to ease the transition to longer working lives.
\end{abstract}




\subsection{Introduction}

Population aging is driving the need for longer working lives in developed countries across the globe (OECD, 2017). As the relative share of older individuals in both the workforce and the overall population increases many societies are trying to promote labor force participation and postpone the timing of retirement of older workers by implementing policy reforms. It is clear that these reforms have substantial implications for the current generation of older workers. They have to work far more years than they had anticipated in order to receive their pension income. In many cases, older workers have had to postpone their retirement unexpectedly, which has sometimes led to resentment, disillusionment and a drop in motivation (Van Solinge \& Henkens, 2017).

When the share of older workers is increasing, the implications for the employers and organizations employing those older workers are likely to be substantial. Employers are confronted with greater shares of older workers in their organizations, who are likely to stay employed for a longer time than both the older workers themselves and their employers had envisioned (Oude Mulders, 2016). However, how employers deal with these issues remains a largely unanswered question. While most of the research in this field has focused on the employee's perspective of working longer, research from the employer's perspective is relatively scarce. Understanding how employers view the aging workforce and how they adjust their human resource (HR) policies and practices in response to an aging workforce is crucial for a deeper understanding of the labor force dynamics of aging societies (Henkens et al., 2017). After all, employers are essential actors in shaping employment opportunities for older workers, and their attitudes and behavior may constrain the options that are available for older workers. In this chapter, we therefore address these issues, focusing on the case of the Netherlands, a country that 
was characterized by high rates of early retirement in the recent past, but that is now transitioning to a society with comparatively high labor force participation rates of older workers and an increasing age of labor force exit (Visser et al., 2016).

We pose the central research question: In which ways have employers adapted their attitudes and organizational policies and practices to deal with an aging workforce? We do so by comparing results from two surveys about the effects of an aging workforce on attitudes and organizational policies and practices among Dutch employers. One of the surveys was conducted in 2009, the other one in 2017. In our comparison of employers' policies and practices from 2009 and 2017, we focus on what we consider to be five central aspects that concern employers in an aging society. First, we study how employers view the development of labor costs and labor productivity, two main factors associated with the employment of older workers, in a continuously aging society. Second, we examine the extent to which employers use specific HR practices in order to manage an aging workforce, in particular focusing on policies directed at increasing the employability of older workers. Third, we focus on the development of employers' age-related workplace norms over time. We look at how norms about the appropriate timing of retirement have changed in tandem with the increase of the statutory retirement age and actual ages of labor force exit. Fourth, we study changes in employers' recruitment practices. Earlier research has shown that many employers have age biases in their recruitment of new personnel, leading to high levels of old age unemployment. An important question is whether the position of older workers has improved in recent years. Fifth, we study employers' preferences for future public policy adjustments, aimed at a better functioning of the labor market in an aging society. Although this study is carried out in the Netherlands, we believe that our analyses 
provides important insights for other countries developing retirement reforms to deal with an aging population.

The remainder of this chapter is organized as follows. Next, we will first discuss the demographic and policy context of the Netherlands, providing information about the extent of population aging and the policy changes that have led to increased labor force participation and increasingly longer working lives. Then, we briefly discuss the methods of the two surveys that we analyze, held in 2009 and 2017 among a representative sample of Dutch employers. Then, we discuss the empirical findings, focusing on the topics described above. In our analyses we will focus on the changes of employers' responses over time. Sectoral differences are not the main focus of this chapter. We will mention sectoral differences only where they seem relevant. Finally, in the discussion section we analyze the biggest changes in employers' attitudes and behavior and discuss possible future developments.

\subsection{Demographic and Policy Context in the Netherlands}

The population of the Netherlands, like that of most other developed countries, is aging rapidly and will continue to age for several decades. This is mainly the result of two demographic developments that have coincided in the post-World War II decades: declining fertility rates and increasing life expectancy. First, fertility rates have declined sharply, mainly between the 1950s and 1980s. For example, Dutch women born in 1935 had on average 2.5 children, whereas women born in 1965 had on average 1.8 children, a rate which has since stabilized and is projected to remain at this level (Van Duin \& Stoeldraijer, 2014). Second, life expectancy has increased substantially in the same period. For example, life expectancy at age 65 was on average 14 (men) and 17 (women) years in 1960 but had increased to 20 (men) and 22 
(women) years in 2014. While the rate of increases in life expectancy has slowed down a little, the trend towards longer lives is projected to continue (Van Duin \& Stoeldraijer, 2014).

These demographic developments will give rise to changes in the relative shares of different age groups in the population. It is estimated that the relative share of older people (i.e., aged $65+$ ) in the Netherlands will increase from approximately 18 per cent now to about 26 per cent in 2040, whereas the share of people in traditional working age (i.e., aged 20-64) will decrease from approximately 59 per cent now to 52 per cent in 2040. Population aging is currently expected to stabilize around the year 2040, meaning that the relative shares of different age groups will remain roughly the same from that point onwards, and there will be no return to a population age structure with larger shares of younger people (Van Duin \& Stoeldraijer, 2014).

Like in other countries, these demographic developments have put pressure on the sustainability of social security and pension systems in the Netherlands, and the government has implemented numerous labor market and retirement-related policy reforms in recent years to alleviate some of the effects of population aging on government finances. The focus of these policy reforms are mainly to prevent and discourage early retirement from the labor market, a phenomenon that was very common until the early 2000s. In the Netherlands, collectively financed early retirement schemes were designed in the 1970s and 1980s to deal with the growing problem of high unemployment rates, declining industries and growth stagnation. These schemes allowed for older workers to retire several years before reaching the statutory retirement age of 65 , with retirement benefits that were characterized by high replacement rates. In addition, there were generous and flexible 'alternative pathways' into early retirement, most prominently through collectively financed unemployment and disability benefits (Kapteyn \& De Vos, 1998). These generous early exit opportunities created an 'early retirement culture', in which early 
retirement was encouraged, and even expected of older workers to open up jobs for unemployed younger workers (Hofäcker \& Unt, 2013). This resulted in very low employment rates for older workers. Around 1990, the employment rate of older workers reached its lowest point, with just over 50 per cent of men and about 20 per cent of women aged 50-65 in employment. While the employment rate of older women had always been low until that time, especially older men were much more often out of employment than in earlier times.

Since the 1990s, however, governments with aging populations have been reforming their employment and retirement policies to stop the trend towards earlier retirement and instead promote longer working lives. In the Netherlands, the collectively financed early retirement schemes were first converted to schemes with later retirement ages and a larger component of individual savings. Later, in 2006, all fiscal support for early retirement schemes was discontinued, thereby effectively ending the government's support for such schemes. Of course, early retirement is still possible, but it is now financed and designed in an 'actuarially fair' manner: whoever wants to retire earlier than the official retirement age will have to incur pension income penalties, thereby making this route far less attractive than it was before (Euwals et al., 2010). In addition, the generosity and accessibility of unemployment and disability benefits has been greatly reduced by policy changes, which has also made early exit from the labor market difficult (Euwals et al., 2012). Finally, in 2012 the Dutch government passed a law that would increase the eligibility age for the flat-rate public pension gradually from 65 to 67 in 2021, after which it will be tied to changes in average life expectancy at age 65. According to current projections, this will imply the statutory retirement age will increase to about 71 years in 2060 (OECD, 2017). 
These policy changes have had a strong effect on the labor force participation of older workers in the Netherlands. This is illustrated in Figure 14.1, which shows the labor force participation rates of Dutch older workers between 2003 and 2015. There is an increase in the labor force participation of older workers between ages 50 and 59, but the changes are most pronounced for the age group 60-64, with participation in this group rising from 22 per cent in 2003 to 51 per cent in 2015. The increase in labor force participation of older workers aged 65+ is also visible, but is still at a relatively low level. The trend towards later retirement is also evident from the average age at labor force exit, which has increased from 61 years in 2006 to 64 years and 5 months in 2015 (Statistics Netherlands, 2016). The pathways of early exit from the labor market have thus been largely closed off, and there is a clear trend towards longer working lives. With the statutory retirement age gradually increasing and the continued adaptation of older workers to work at higher ages, employment rates of older workers are expected to continue to increase in the near future.

Figure 14.1: Labor force participation rates of older workers in the Netherlands, 2003-2015.

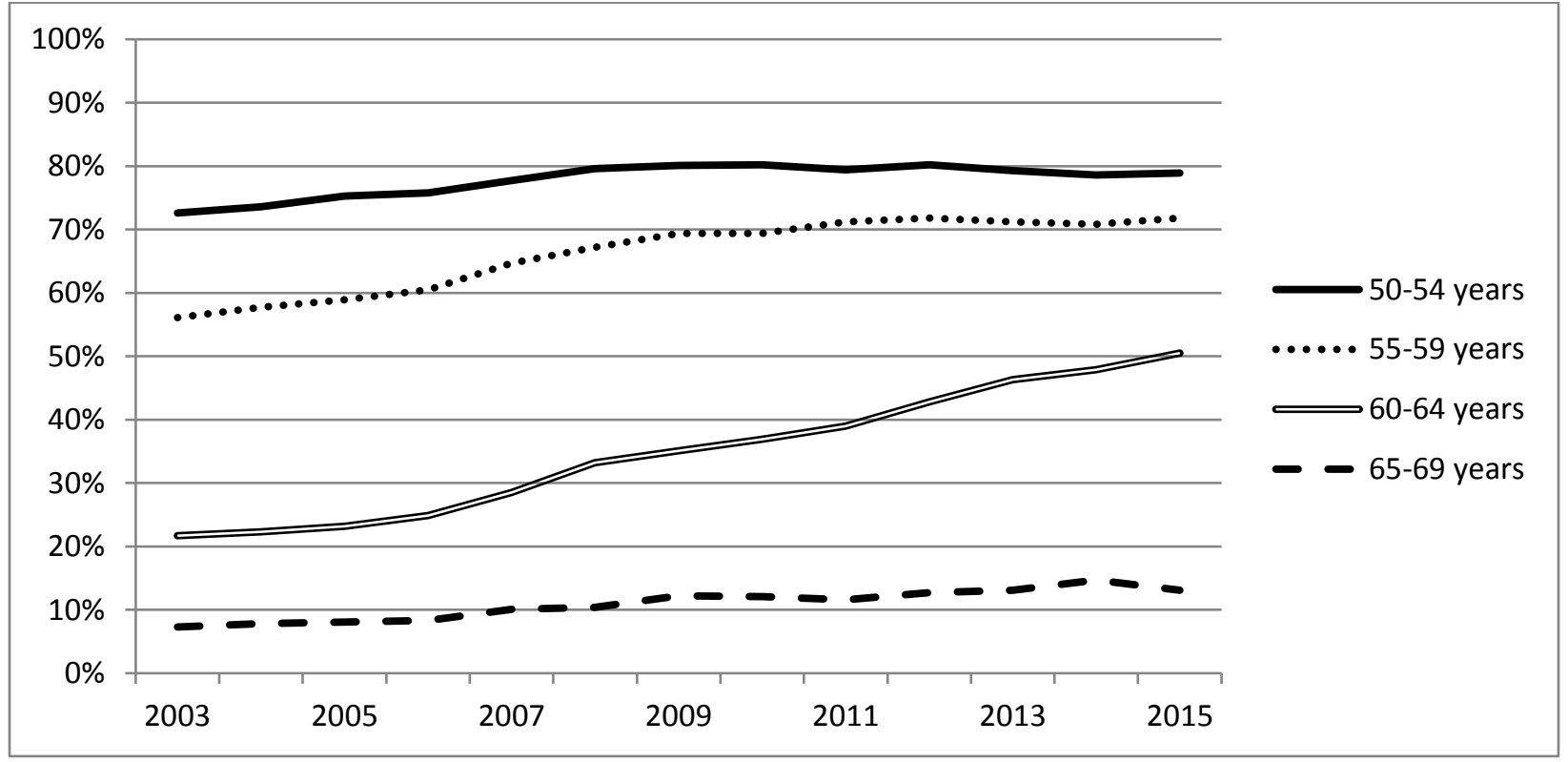

Source: Statistics Netherlands 


\subsection{Methods}

In this chapter, we analyze data from two large-scale surveys of Dutch employers on the topic of workforce aging and longer working lives, one held in 2009, the other held in 2017 . The 2009 survey was part of a larger European project about employers' practices and policies regarding an aging workforce, which involved data collection among employers in eight European countries (for more details see Conen, 2013). Here, we only use data from Dutch employers. These data were collected through a hard-copy survey between February and May of 2009. 1,077 organizations responded, out of a sample of 4,700 organizations, for a response rate of 23 per cent. The sample was stratified according to size and sector, to ensure sufficient responses from a diverse set of organizations. Sample weights were used in the analysis to correct for the sampling design.

The 2017 survey was similar in topic and design to the (Dutch part of the) 2009 survey. A similar sampling approach was chosen, with the sample being stratified according to size and sector, but with sample weights constructed to correct for the sampling design. The data were collected between December 2016 and March 2017, with 1,358 responses out of a sample of 6,000 organizations for a response rate of 23 per cent. The response rate was thus the same as it was in 2009 and is also comparable to other large-scale employer surveys in organizational research, nationally and internationally (Conen et al., 2011; Baruch \& Holtom, 2008). Surveys were mailed hard copy to the organizations, but now an online response option was added, with half of the responses being hard copy, and the other half being online responses. 


\subsection{Costs and Productivity of an Aging Workforce}

One of the central issues associated with the aging of the workforce is the issue of (the perception of) rising costs and declining productivity (Conen et al., 2012). In most organizations, wages increase with organizational tenure, so that older workers are in general more costly for employers than younger workers. Wages rising with seniority fit within implicit contract theory and are meant to keep workers motivated throughout their entire career within the firm (Lazear, 1979). Although seniority wages are common in most jobs, the extent to which wages rise with tenure may differ strongly between organizations, industries, and countries. Earlier research has shown that the presence of the seniority principle in wage setting is more pervasive in the Netherlands than elsewhere, meaning that organizational tenure is rewarded to a larger extent in the Netherlands than in other countries (Conen et al., 2012). This may be partly due to a strong tradition of collective bargaining between employers' and employees' representatives. The Organisation for Economic Co-operation and Development (OECD) has identified the comparatively steep level of seniority-based wages in the Netherlands as a potential problem as population aging continues, and has suggested a wage-setting mechanism that is based more on performance and less on tenure than the current mechanism (OECD, 2014).

A closely related issue is the development of workers' productivity as they age. It is generally acknowledged that workers of different ages have different qualities that may contribute to their productivity, mostly being related to their physical and mental capacities, and the experience and knowledge they have built up over previous years. For example, older workers are generally considered to possess more 'soft skills', such as better social skills and more commitment to the organization, whereas younger workers are generally considered to possess more 'hard skills', such as mental and physical capacities and the willingness to learn 
and apply new technologies to the work process (Van Dalen et al., 2010). Still, studies

examining the relationship between age and productivity find no overall effect of age on general productivity, although links to more specific aspects of job performance have been found ( $\mathrm{Ng} \&$ Feldman, 2008). The extent to which productivity is affected by the aging of the workforce thus seems to depend crucially on the type of job and the specific characteristics of the employees. However, negative stereotypes about older workers' productivity remain persistent and may influence the ways in which employers respond to an aging workforce (Posthuma \& Campion, 2009).

Figure 14.2 shows how employers think labor costs of their organization would develop in the case of continuing workforce aging. The results show a small increase in the proportion of employers that expect rising labor costs. In 2009, 75 per cent of employers expected labor costs would increase as a result of aging staff, whereas in 201781 per cent of employers thought so. Almost no one expected a decrease in labor costs: in 2009 only 1 per cent; in 20170 per cent.

Figure 14.3 shows how employers expect labor productivity will develop in the case of continuing population and workforce aging. Here, the differences between 2009 and 2017 are far more striking. In 2009, 34 per cent of employers expected a decrease in overall productivity, 58 per cent expected productivity to remain roughly the same, and 8 per cent expected an increase in productivity. In 2017, 56 per cent of employers expected a decrease in overall productivity as a result of aging staff, 38 per cent expected it to remain the same, and only 6 per cent expected an increase. Overall, the results indicate that employers have become more pessimistic about the effects of workforce aging. The growing gap between labor costs and productivity in an aging society can have strong implications because when wage costs increase while productivity 
stagnates or declines, profit margins will be under pressure and organizations may need to restructure or downsize.

Figure 14.2: Employers' expected labor costs in case of a continuing aging workforce

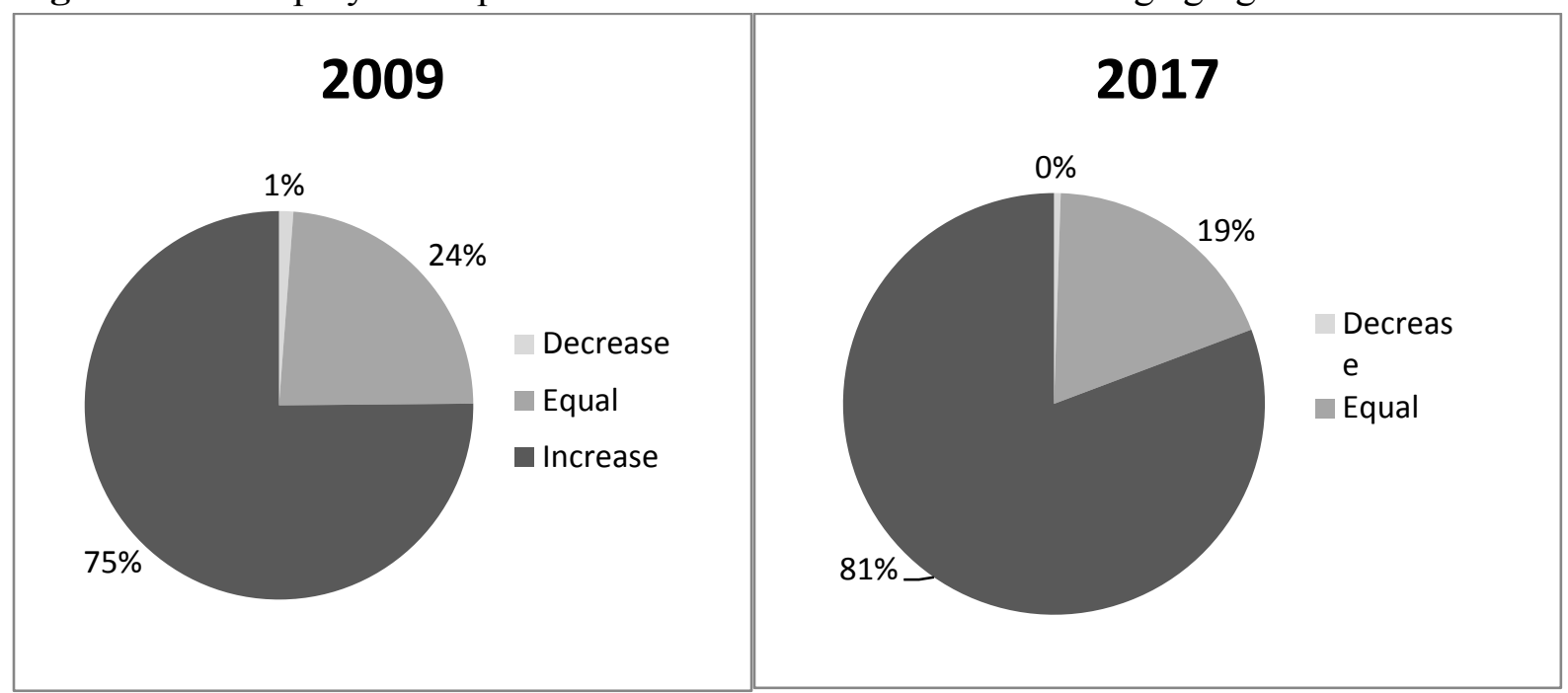

Note: Based on the question "If the average age of your workforce would increase by five years, what would be the effect on labor costs?"

Source: Employers' surveys 2009 \& 2017

Figure 14.3: Employers' expected labor productivity in case of a continuing aging workforce

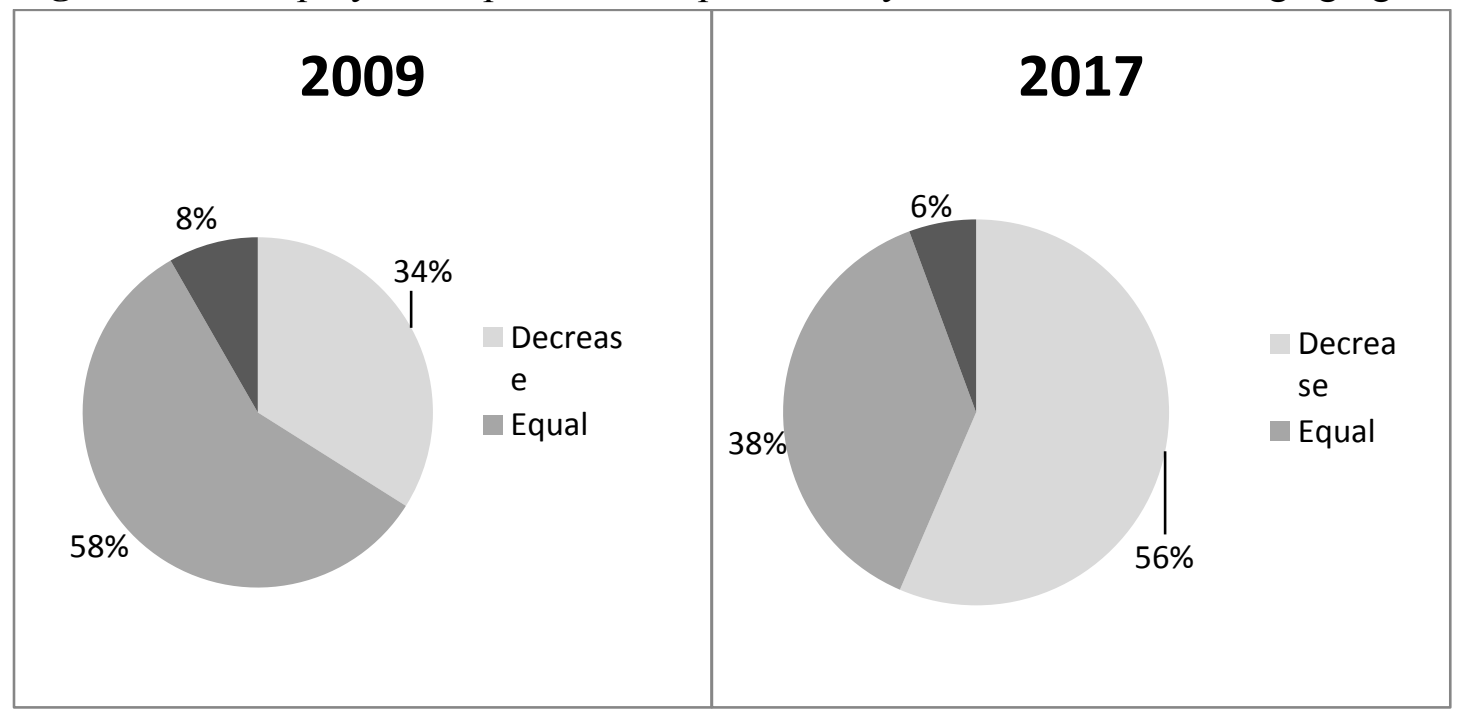

Note: Based on the question "If the average age of your workforce would increase by five years, what would be the effect on labor productivity?"

Source: Employers' surveys 2009 \& 2017 
These results are worrisome, because longer working lives are a new 'fact' employers have to deal with. In particular, the concerns about productivity seem to reflect the decrease in the opportunities for employers to provide an easy exit to less productive older workers before statutory retirement age since 2009. Instead, the statutory retirement age has also been increased gradually, and will continue to increase in the near future, implying that employers need to employ their older workers even longer in the future. Especially when it comes to heavy physical labor, employers may expect a decline in productivity at later ages.

\subsection{Investing in Older Workers' Work Ability}

While employers' views about the costs and productivity of an aging workforce provide valuable information about why many employers view population aging as a challenge, it does not reveal which strategies or policies employers choose to deal with an aging workforce. This information might be extracted more directly through their application of different HR practices that affect the work ability of employees. The application of HR practices serves multiple important functions, such as creating working conditions for different sets of employees, creating opportunities for employees' individual development, but also signaling an organization's strategic purposes and intentions towards current and prospective staff (Rau \& Adams, 2013). HR practices aimed specifically at older workers are especially important for understanding how organizations deal with an aging workforce, since organizations may use their HR practices to, for example, encourage or discourage working until or even after retirement (Oude Mulders et al., 2017). Van Dalen and colleagues (2015) offer a useful taxonomy of age-based HR practices, distinguishing three types: (1) accommodation practices to compensate for the possible decline in physical and cognitive capacities of older workers, (2) development practices to increase the 
productive capacity of older workers, and (3) exit practices that enable older workers to retire from the labor force, either fully or partially.

Figure 14.4 shows how often Dutch employers have applied a number of HR practices that affect working conditions and work ability of older workers. The results clearly show a moderate to strong increase in the application of most of the HR practices, mostly accommodative and development practices, but a decrease in exit practices. More than half of Dutch employers now offer one or more accommodation measures, aimed at compensating the potential age-related loss in physical and cognitive functioning. Offering flexible working hours and ergonomic measures are the most commonly applied accommodative HR practices, with over half of the employers offering those measures. The increase in offering additional leave for older workers is striking, given that this is a typical HR practice that can be perceived as increasing the costs associated with employing older workers. Still, the increase in the application of this measure shows that many employers think allowing older workers to take additional leave improves their work ability in the long run, possibly by reducing the risk of absence due to illness.

Demotion - the reduction of an employee's rank and salary - is often mentioned by managers and policy makers as a means of increasing the employability of older workers in an aging labor force. However, in practice demotion is rarely applied (Bowlus \& Robin, 2012; Josten \& Schalk, 2010). Our results indicate that although the percentage of organizations that use demotion for older workers as an instrument of HR policy has more than doubled, it is still quite rare, and the least applied policy instrument. Most likely this is due to the fear that the application of demotion will demotivate other employees (Van Dalen \& Henkens, 2016; Verheyen \& Guerry, 2018). 
Even though there is a clear overall increase in the application of accommodation measures, the biggest difference in employers' HR practices between 2009 and 2017 is the large increase in the application of the development-related HR practice of offering training opportunities to older workers, with only 8 per cent of employers offering this in 2009 , but 40 per cent offering it in 2017. It seems Dutch employers are embracing the potential benefits of lifelong learning and are realizing that offering training opportunities to older workers can increase their long-term work ability, thus also being beneficial to the organization. Finally, there is a very clear decline in the application of exit-related HR practices. Offering part-time retirement arrangements to older workers, thereby allowing them to partially retire before their full retirement, has decreased considerably, with 29 per cent of employers offering part-time retirement in 2009, and 13 per cent offering such arrangements in 2017.

Figure 14.4: Employers' application of age-based HR policies

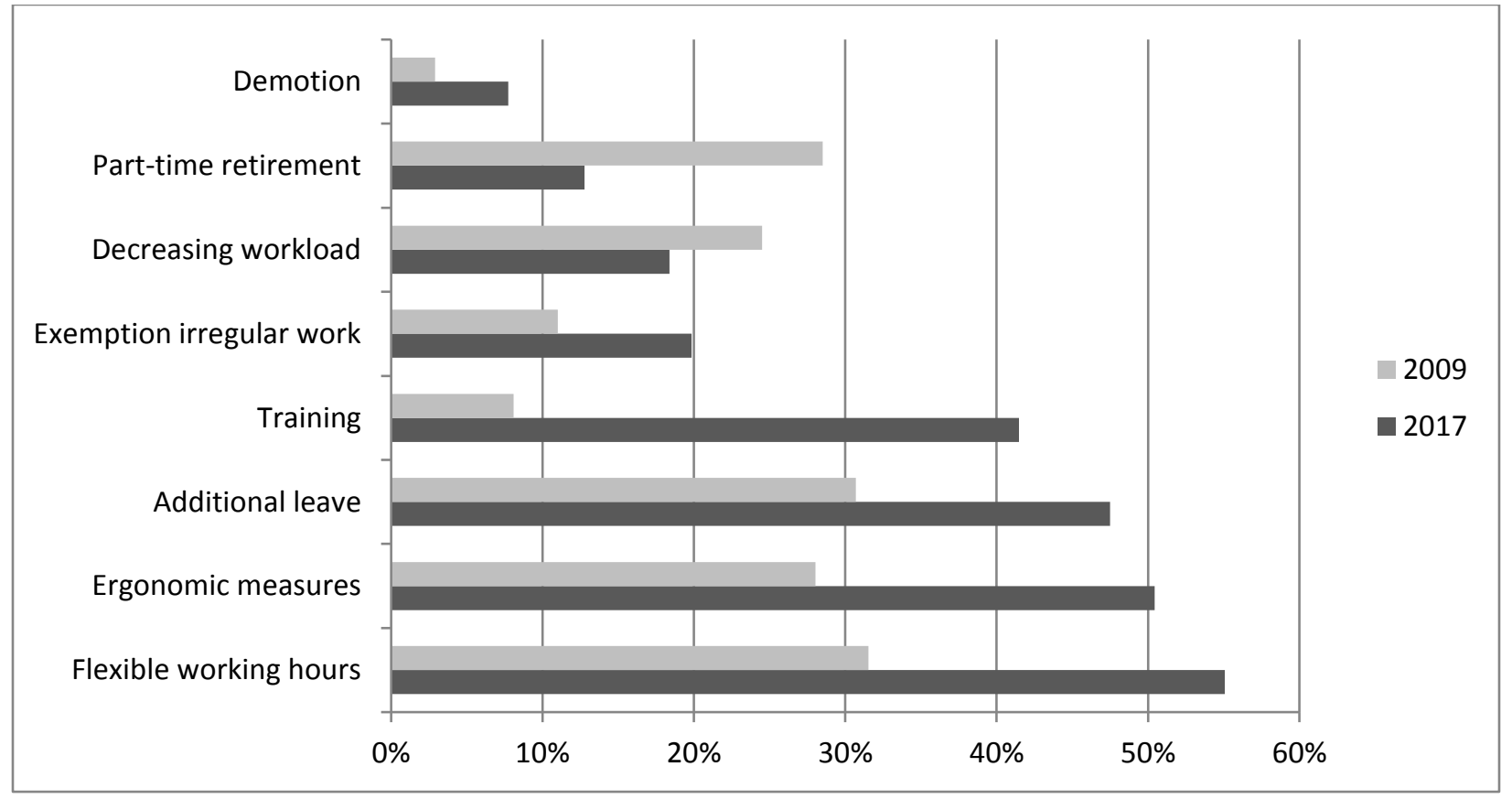

Note: Based on the question "Which of the following HR policies are applied in your organization?"

Source: Employers’ surveys 2009 \& 2017 
The increase in the application of accommodative and development age-based HR policies should be seen within the Dutch labor market context. Due to relatively high level of employment protection legislation, it is difficult and costly to dismiss older workers. Given that the opportunities for early exit from the labor market have also been strongly diminished, organizations have a vested interest to ensure the work ability of older workers until they reach mandatory retirement age, which is coupled to the statutory retirement age. This has most likely increased the need to invest in the long term mental and physical fitness of older workers, driving the increase of development and accommodation HR practices. The decrease in offering exit opportunities should also be viewed in this context. While many older workers see part-time retirement before full retirement as an attractive option, both employers and employees have been shown to be reluctant to implement it due to the high costs associated with (partial) early exit from the labor market. Overall, the changes in employers' application of age-based HR policies shows a growing sense of urgency among employers to ensure long-term work ability of older workers.

\subsection{Retirement Age Norms}

The normative context in which decisions regarding the employment of older workers are taken is another important factor to consider. Individuals, including important organizational actors such as CEOs or (top) managers, have normative ideas about factors such as the appropriate timing of retirement, which may affect the ways in which they deal with the problem of workforce aging (Oude Mulders et al., 2017; Radl, 2012; Settersten \& Hagestad, 1996). Such age-related workplace norms may stem from factors such as personal values about the appropriateness of working at later ages, individual experiences with older workers, observed 
attitudes and behavior of others, but also from institutional factors such as a statutory retirement age coupled to a public pension and mandatory retirement regulations.

The retirement age norm is an important normative concept that taps into a person's expectations about the appropriate timing of retirement, or at what age workers should retire. It may specify a single age at which one thinks people should retire, or it may specify lower and upper boundaries between which the retirement transition should occur. The retirement age norm held by important organizational actors has proven to be an important predictor in employers' behavior regarding older workers. For example, the retirement age norm influences decisions such as about the retention of older workers (Karpinska et al., 2013), hiring of (early) retirees (Oude Mulders et al., 2014), but also more broadly organizational practices aimed at extending working lives (Oude Mulders et al., 2017).

Table 14.1 shows the lower and upper boundaries of the retirement age norm from Dutch employers in 2009 and 2017. The lower boundary indicates the age at which employers think workers are generally too young to retire, whereas the upper boundary indicates the age at which employers think workers are too old to work for at least 20 hours a week. Additionally, Table 14.1 shows the statutory retirement ages in those years, as well as the average age of actual labor market exit in the Netherlands. The table shows an overall increase in both the lower and the upper boundary of the retirement age norm from 2009 to 2017, with the lower boundary increasing from 58.9 to 59.9 years, and the upper boundary increasing from 66.4 to 67.6 years. The statutory retirement age increased from 65 in 2009 (up until 2012) to 66 in 2017, and will increase to 67 in 2021. The average age of labor market exit increased from 62.5 to 64.4 from 2009 to 2017. 
Table 14.1: Employers' age norms regarding the appropriate age of retirement, statutory retirement ages, and average ages of labor market exit in 2009 and 2017

\begin{tabular}{|c|c|c|c|c|}
\hline & \multicolumn{2}{|c|}{2009} & \multicolumn{2}{|c|}{2017} \\
\hline & Mean & S.D. & Mean & S.D. \\
\hline $\begin{array}{l}\text { Retirement age norm } \\
\text { Lower boundary } \\
\text { Upper boundary }\end{array}$ & $\begin{array}{l}58.9 \\
66.4 \\
\end{array}$ & $\begin{array}{l}4.0 \\
4.8\end{array}$ & $\begin{array}{l}59.9 \\
67.6 \\
\end{array}$ & $\begin{array}{l}5.4 \\
5.0\end{array}$ \\
\hline $\begin{array}{l}\text { Statutory retirement age } \\
\text { Average age of labor market exit }\end{array}$ & \multicolumn{2}{|c|}{$\begin{array}{c}65 \\
62.5\end{array}$} & \multicolumn{2}{|c|}{$\begin{array}{c}66^{*} \\
64.4^{* *}\end{array}$} \\
\hline
\end{tabular}

Note: Based on the questions "At which age do you in general consider a person too young to retire?" (lower boundary) and "At which age do you in general consider a person too old to work 20 hours a week or more?" (upper boundary)

* The statutory retirement age was gradually increased throughout 2017; it was 66 at the end of 2017. ** Figure from 2016, as this was the latest available data.

Source: Employers' surveys 2009 \& 2017

While norms are relatively slow to change it is interesting to note that the retirement age norm gradually seem to change in response to increases in the statutory retirement age and the average age at labor market exit in recent years. At the same time the figures show increasing diversity among the age norms of employers. In 2017, 43 per cent of employers reported a upper boundary retirement age norm that was lower than the statutory retirement age at that time, whereas in 2009 only 17 per cent did so. This suggests that employers - although adjusting to higher retirement ages - have concerns about the pace of increasing the retirement age.

\subsection{Older Workers and Shortages on the Labor Market}

Longer working lives not only manifest through continued employment of older workers, but also by unemployed older workers being hired and older workers switching jobs. Traditionally labor shortages are deemed to be the most effective stimulus for the position of 
older workers in the labor market. Here, we analyze which practices employers turn to when they are confronted with a shortage of suitable personnel. The results from both surveys are presented in Table 14.2, with the results being divided into subcategories, focusing on certain target groups (such as older workers, females or migrants), practices aimed at current employees, and practices aimed at reducing labor demand.

The results show that, overall, employers applied a more diverse range of practices in 2017 than they did in 2009. Looking more closely, we can see that there is an increase in practices aimed at certain target groups, mainly focusing more on the employment of women, especially in male-dominated industries and for top positions in organizations. However, there is no change in focus on hiring older workers, with just 10 per cent of employers focusing on hiring older workers in case of shortages. This is in contrast with findings that showed an increased likelihood of hiring older workers in better economic conditions (Oude Mulders et al., 2018). Employers also do not focus more on increasing the productivity of current employees. An equal proportion of employers (17 per cent) in 2017 encourage their employees to work until statutory retirement age as they did in 2009 , whereas encouraging workers to work beyond the statutory retirement age has decreased from 8 per cent in 2009 to 6 per cent in 2017. Of course, this is likely to be related to the increasing statutory retirement age (see Table 14.1 or the policy context above), which already led to older workers working longer than before. The biggest increase in employers' practices, however, comes from practices that are aimed at reducing labor demand. Especially outsourcing labor has become far more popular, with an increase from 4 per cent in 2009 to 25 per cent in 2017. This is likely the result of changing economic conditions: in 2009 the Dutch economy was still feeling the effects of the global financial crisis of 2007-2008 and was experiencing a strong growth in unemployment, whereas in 2017 the Dutch economy had 
recovered from the economic crises of the past decade and the labor market is showing shortages in many sectors.

Table 14.2: Employers' hiring and retention practices in case they encounter labor market shortages

\begin{tabular}{lll}
\hline & 2009 & 2017 \\
\hline Practices aimed at target groups & \multicolumn{2}{c}{} \\
\hline Recruiting more women workers & $19 \%$ & $29 \%$ \\
Offering higher wages & $16 \%$ & $17 \%$ \\
Recruiting more older workers & $10 \%$ & $10 \%$ \\
Recruiting staff from abroad & $8 \%$ & $10 \%$ \\
Recruiting former staff that has taken (early) retirement & $4 \%$ & $4 \%$ \\
\hline Practices aimed at current employees & \multicolumn{3}{c}{$17 \%$} & $17 \%$ \\
\hline Encouraging workers to work until statutory retirement age & $7 \%$ & $11 \%$ \\
Working more hours & $8 \%$ & $6 \%$ \\
Encouraging workers to work beyond statutory retirement age & $4 \%$ & $25 \%$ \\
\hline Practices aimed at reducing labor & $15 \%$ & $22 \%$ \\
\hline Outsourcing labor & $4 \%$ & $5 \%$ \\
Substituting technology for labor & & \\
Relocating production capacity abroad & \multicolumn{3}{c}{} \\
\hline
\end{tabular}

Note: Based on the question "If you are or were to be confronted with a shortage of suitable personnel, which practices do you or would you consider?"

Source: Employers' surveys 2009 \& 2017

\subsection{Future Policy Reforms}

Of course, not only employers and employees play an important role in the labor market. As mentioned earlier, the government also plays an important role in shaping the context for longer working lives with its labor market and retirement-related public policies. In the public debate, there is a lot of attention for longer working lives, with many commenters pointing to the growing inequality between lower and higher educated workers and solidarity between generations. Some argue that the current policy that will lead to a statutory retirement age above 
age 70 by 2060 is unsustainable, especially for lower educated older workers and those in physically demanding jobs. This is also reflected in, for example, the high levels of discontent among low educated workers about the implemented public pension reforms (Van Solinge \& Henkens, 2017). Many people are calling for additional policy reforms to alleviate the effects of workforce aging and make longer working lives more attainable.

Table 14.3 presents a number of possible policy reforms to that end, and the extent to which employers support those reforms. It is clear that the increasing public pension age is considered to be the biggest issue, especially for physically demanding jobs: 79 per cent of employers support a lower statutory retirement age for workers in such jobs. Almost two thirds of employers are also in favor of a more flexible labor market, which could be attained by relaxing the employment protection legislation and making dismissal of employees easier and less costly. While this may make the problems associated with workforce aging smaller for employers, it may also lead to increasing unemployment among older workers, especially considering employers' assessments of the costs and productivity of older workers (see Figures 14.2 and 14.3). Sixty-one per cent of employers are in favor of the government stimulating, possibly by subsidizing, part-time retirement, as this may make the transition from full-time work to full-time retirement easier. This could potentially contribute to longer working lives, if workers take part-time retirement instead of full-time retirement, but could also hamper the transition, if workers take part-time retirement instead of working full-time but do not postpone their full retirement. Over half of the employers also would like to see the government stimulating the possibility of demotion, most likely because this could decrease the costs associated with workforce aging and may bring the productivity of older workers in line with 
their wages. Finally, 45 per cent of employers are supportive of decreasing the strength of seniority wages in the Netherlands, as was suggested by the OECD (2014).

Table 14.3: Employers' desired policy reforms

\begin{tabular}{ll}
\hline & 2017 \\
\hline Lower retirement age for heavy physical labor & $79 \%$ \\
More flexible labor market & $64 \%$ \\
Stimulating part-time retirement & $61 \%$ \\
Stimulating demotion & $57 \%$ \\
Decreasing seniority wages & $45 \%$ \\
\hline
\end{tabular}

Note: Based on the question "Older workers need to work longer than before. Related to this, which public policies do you find desirable?"

Source: Employers' survey 2017

\subsection{Discussion}

After decades in which workers and employers used the exit route of early retirement, current retirement reforms force both employers and employees to adjust to the idea of extending working life (Beehr \& Bennett, 2015). The development and implementation of pension reforms aimed at longer working lives can be witnessed in most developed countries. While increasing evidence shows how older workers extend their careers in response to these pension reforms, much less is known about employers' attitudes and behaviors. In this chapter we analyzed responses of Dutch employers to workforce aging over the past decade.

The results indicate that employers have become increasingly involved in managing their aging personnel. With respect to their HR policies and practices we see a clear tendency to invest in the productivity of older workers. Employers are more likely to provide training to their older workers than in the recent past. Also, accommodative policies, such as flexible work schedules and ergonomic measures have become more prevalent. The existence of policies aimed at an 
early exit route have decreased. In addition, the workplace norms about the appropriate retirement age are gradually increasing in line with the increasing retirement age. As such, one might conclude that employers are highly responsive to the increasing retirement ages enforced by the recent public policy reforms. At the same time, however, the results indicate growing concerns among employers about the lack of flexibility that the pension system offers to employers and older workers in managing the retirement transition. Our findings show that expectations of employers have become far more pessimistic in the past decade about how an aging workforce will affect labor productivity. Furthermore, there is overwhelming support among employers for public policies to support earlier exit for those in physically demanding occupations and for stimulating part-time retirement.

In short, employers' responses to the aging workforce are a double-edged sword: Employers are becoming more proactive in investing in the work ability of older workers and accommodating longer working lives, but also still feel the need for an early retirement option for older workers whose capacity to work until high ages is limited. This may well become a stylized fact of the present and future organization where employing workers aged 60 years and older is no longer an exception but the rule.

\section{References}

Baruch, Y., \& Holtom, B.C. (2008). Survey response rate levels and trends in organizational research. Human Relations, 61(8), 1139-1160.

Beehr, T.A., \& Bennett, M.M. (2015). Working after retirement: Features of bridge employment and research directions. Work, Aging and Retirement, 1(1), 112-128.

Bowlus, A.J., \& Robin, J.-M. (2012). An international comparison of lifetime inequality: How continental Europe resembles North America. Journal of the European Economic Association, 10(6), 1236-1262. 
Conen, W.S. (2013). Older workers: The view of Dutch employers in a European perspective. Amsterdam: Amsterdam University Press.

Conen, W.S., Henkens, K., \& Schippers, J.J. (2011). Are employers changing their behavior toward older workers? An analysis of employers' surveys 2000-2009. Journal of Aging \& Social Policy, 23(2), 141-158.

Conen, W.S., Van Dalen, H.P., \& Henkens, K. (2012). Ageing and employers' perceptions of labour costs and productivity: A survey among European employers. International Journal of Manpower, 33(6), 629-647.

Euwals, R., Van Vuuren, D., \& Wolthoff, R. (2010). Early retirement behaviour in the Netherlands: Evidence from a policy reform. De Economist, 158(3), 209-236.

Euwals, R., Van Vuren, A., \& Van Vuuren, D. (2012). The decline of substitute pathways into retirement: Empirical evidence from the Dutch health care sector. International Social Security Review, 65(3), 101-122.

Henkens, K., Van Dalen, H.P., Ekerdt, D.J., Hershey, D.A., Hyde, M., Radl, J., Van Solinge, H., Wang, M., \& Zacher, H. (2017). What we need to know about retirement: Pressing issues for the coming decade. The Gerontologist, Advance Access June 20, 2017. http://dx.doi.org/10.1093/geront/gnx095

Hofäcker, D., \& Unt, M. (2013). Exploring the 'new worlds' of (late?) retirement in Europe. Journal of International and Comparative Social Policy, 29, 163-183.

Josten, E., \& Schalk, R. (2010). The effects of demotion on older and younger employees. Personnel Review, 39, 195-209.

Kapteyn, A., \& De Vos, K. 1998. Social security and labor force participation in the Netherlands. American Economic Review, 88, 164-167.

Karpinska, K., Henkens, K., \& Schippers, J. (2013). Retention of older workers: Impact of managers' age norms and stereotypes. European Sociological Review, 29(6), 1323-1335.

Lazear, E.P. (1979). Why is there mandatory retirement? Journal of Political Economy, 87(6), 1261-1284.

Ng, T.W.H., \& Feldman, D.C. (2008). The relationship of age to ten dimensions of job performance. Journal of Applied Psychology, 93(2), 392-423.

OECD (2014). Ageing and Employment Policies: Netherlands: Working Better With Age. Paris: OECD Publishing. http://dx.doi.org/10.1787/9789264208155-en

OECD (2017). Pensions at a Glance 2017: OECD and G20 Indicators. Paris: OECD Publishing. http://dx.doi.org/10.1787/pension_glance-2017-en

Oude Mulders, J. (2016). Organizations, managers, and the employment of older workers after retirement. Utrecht: Tjalling C. Koopmans Dissertation Series. https://dspace.library.uu.nl/handle/1874/337479

Oude Mulders, J., Henkens, K., Liu, Y., Schippers, J., \& Wang, M. (2018). Managers' interview invitation decisions about older job applicants: Human capital, economic conditions and job demands. Ageing \& Society, 38(4), 839-864. 
Oude Mulders, J., Henkens, K., \& Schippers, J. (2017). European top managers' age-related workplace norms and their organizations' recruitment and retention practices regarding older workers. The Gerontologist, 57(5), 857-866.

Oude Mulders, J., Van Dalen, H.P., Henkens, K., \& Schippers, J. (2014). How likely are employers to rehire older workers after mandatory retirement? A vignette study among managers. De Economist, 162, 415-431.

Posthuma, R.A., \& Campion, M.A. (2009). Age stereotypes in the workplace: Common stereotypes, moderators, and future research directions. Journal of Management, 35, 158188.

Radl, J. (2012). Too old to work, or too young to retire? The pervasiveness of age norms in Western Europe. Work, Employment \& Society, 26(5), 755-771.

Rau, B.L., \& Adams, G.A. (2013). Aging, retirement, and human resources management: A strategic approach. In M. Wang (Ed.), The Oxford Handbook of Retirement (pp. 117-135). Oxford, UK: Oxford University Press.

Settersten, R.A., \& Hagestad, G.O. (1996). What's the latest? II. Cultural age deadlines for educational and work transitions. The Gerontologist, 36(5), 602-613.

Statistics Netherlands (2016b). Van arbeid naar pensioen; personen 55 jaar of ouder. Retrieved March 1, 2016, from http://statline.cbs.nl/

Van Dalen, H.P., \& Henkens, K. (2016). Why demotion of older workers is a no-go area for managers. The International Journal of Human Resource Management, Advance Access, 3 October 2016,

Van Dalen, H.P., Henkens, K., \& Schippers, J. (2010). Productivity of older workers: Perceptions of employers and employees. Population and Development Review, 36(2), 309-330.

Van Dalen, H.P., Henkens, K., \& Wang, M. (2015). Recharging or retiring older workers? Uncovering the age-based strategies of European employers. The Gerontologist, 55(5), 814-824.

Van Duin, C., \& Stoeldraijer, L. 92014). Bevolkingsprognose 2014-2060: Groei door migratie. Den Haag/Heerlen: CBS.

Van Solinge, H., \& Henkens, K. (2017). Older workers' emotional reactions to rising retirement age: The case of the Netherlands. Work, Aging and Retirement, 3(3), 273-283.

Verheyen, T. \& Guerry, M.-A. (2018). Motives for (non) practicing demotion. Personnel Review, 40(2), 244-263.

Visser, M., Gesthuizen, M., Kraaykamp, G., \& Wolbers, M.H.J. (2016). Trends in labour force participation of older men: Examining the influence of policy reforms, normative change and deindustrialization in the Netherlands, 1992-2009. Economic and Industrial Democracy, 37(3), 425-447. 